\title{
POTENSI KEBANGKRUTAN PADA SEKTOR PERBANKAN SYARIAH UNTUK MENGHADAPI PERUBAHAN LINGKUNGAN BISNIS
}

\author{
Dwi Nur'aini Ihsan \& Sharfina Putri Kartika \\ UIN Syarif Hidayatullah Jakarta \\ mydwinuraini@uinjkt.ac.id; sharfina@yahoo.co.id
}

\begin{abstract}
.
This research aims to evaluate the soundness of Islamic banks and to predict the bankruptcy potency from the Islamic banks. The methods that used on this paper are RGEC method and the modified altman z-score analysis. The RGEC represents by NPF, LR, risk profile, ROA, NCOM, and CAR. The altman z-score represents by the ratio of networking capital to total asset, retained earning to total asset, earning before interest and tax to total asset, and book value of equity to book value of debt. The result showed that the Islamic bank's soundness used RGEC methods is fit into healthy category in 20102014 periods. The altman z-score also show that the Islamic banks fit into safe zone in 2010-2014 periods.
\end{abstract}

Keywords: Islamic bank; bankruptcy; RGEC; altman z-score

\begin{abstract}
Abstrak.
Penelitian ini bertujuan untuk menilai tingkat kesehatan dari bank umum syariah dan juga memprediksi potensi kebangkrutan dari bank umum syariah itu sendiri. Model analisis yang digunakan adalah metode RGEC dan model analisis Altman Z-Score modifikasi. Metode RGEC pengukurannya diwakili oleh rasio NPF, LR, Profil Risiko, ROA, NCOM, dan CAR. Model Altman z-score pengukurannya akan diwakili oleh rasio model kerja bersih terhadap aset, laba ditahan terhadap total aset, laba sebelum bunga dan pajak terhadap total aset, dan nilai buku modal terhadap nilai buku hutang. Hasil penelitian menunjukkan tingkat kesehatan bank umum syariah menggunakan metode RGEC masuk ke dalam kategori yang "sehat" selama tahun 2010-2014. Model Altman zscore juga menunjukkan bahwa bank umum syariah berada pada keadaan yang safe zone (tidak bangkrut) selama tahun 2010 sampai dengan tahun 2014.
\end{abstract}

Kata Kunci: bank syariah; kebangkrutan; RGEC; altman z-score

Diterima: 1 Maret 2015; Direvisi: 25 April 2015; Disetujui: 5 Mei 2015 


\section{PENDAHULUAN}

Perekonomian Indonesia tidak luput dari imbas dinamika pasar keuangan global. Salah satu imbas dari dinamika ini adalah krisis ekonomi yang terjadi pada tahun 2008 yang berakibat pada sektor perbankan di Indonesia, terutama untuk bank konvensional. Hal ini dikarenakan bank konvensional memiliki tingkat integritas yang tinggi dengan sistem keuangan global. Dapat dilihat pada Oktober 2008 Bank Mandiri Tbk, Bank Negara Indonesia Tbk, dan Bank Rakyat Indonesia Tbk meminta bantuan likuiditas dari Bank Indonesia.

Berbeda dengan bank konvensional, perbankan syariah tidak terlalu mengalami dampak negatif dari krisis ekonomi global yang terjadi. Meski pada masa krisis keuangan tersebut perbankan syariah dapat bertahan dan dapat mengatasi masalah-masalah yang terjadi dalam kegiatan usahanya, namun bank syariah sebagai lembaga keuangan yang berorientasi terhadap keuntungan tentu akan tetap menghadapi berbagai risiko yang tidak menutup kemungkinan mengancam eksistensinya.

Bank yang tidak mampu bersaing untuk mempertahankan kinerjanya lambat laun akan tergusur dari lingkungan industrinya dan akan mengalami kebangkrutan, demikian pula dengan perbankan syariah. Oleh karena itu untuk mengantisipasi berbagai risiko yang mungkin terjadi, diperlukan suatu tindakan sedini mungkin untuk mengukur kondisi serta tingkat kesehatan perbankan syariah itu sendiri. Sistem peringatan dini (early warning system) untuk memprediksi adanya keadaan kesulitan keuangan (financial distress) yang menuju ke arah kebangkrutan ada beberapa model analisis yang sering digunakan, salah satunya yang terkenal adalah model Altman Z-Score yang dikemukakan oleh Edward I. Altman pada tahun 1968.

Model analisis ini menggunakan rasio-rasio tertentu sebagai model prediksi dengan menggunakan teknik Multiple Discriminant Analysis (MDA). Rasio-rasio yang digunakan mencerminkan rasio likuiditas, profitabilitas, leverage, dan aktivitas perusahaan. Dengan adanya kombinasi dari rasio-rasio tersebut, maka model analisis ini akan sangat membantu untuk mengetahui kinerja keuangan perusahaan dan dapat membantu juga dalam memprediksi potensi kebangkrutan yang mungkin dialami oleh sebuah perusahaan. Penilaian 
potensi kebangkrutan dimaksudkan untuk menilai keberhasilan perbankan dalam perekonomian Indonesia, dalam industri perbankan sendiri, mengukur tingkat kesehatan dari bank itu sendiri dalam menjaga fungsi intermediasi, serta untuk peringatan dini dalam menghadapi perubahan di lingkungan bisnis perbakan itu sendiri atau perubahan ekonomi negara .

Masalah kebangkrutan pada suatu perusahaan termasuk bagi bank umum syariah merupakan sebuah risiko yang tidak dapat dihindarkan, namun risiko ini dapat diminimalisasi atau dicegah. Kebangkrutan sendiri merupakan akibat dari hasil kinerja negatif yang dilakukan oleh bank umum syariah. Untuk mengetahui kinerja bank umum syariah baik atau tidak dapat dilihat dari tingkat kesehatan bank umum syariah tersebut. Penilaian tingkat kesehatan bank umum syariah dapat menggunakan model analisis RGEC berdasarkan Peraturan Otoritas Jasa Keuangan Nomor 8/POJK.03/2014 Tentang Penilaian Tingkat Kesehatan Bank Umum Syariah Dan Unit Usaha Syariah.

Setelah melakukan pengukuran tingkat kesehatan bank, maka kemudian dilakukan analisis untuk memprediksi potensi kebangkrutan bank umum syariah tersebut. Model analisis yang digunakan adalah Multiple Discriminant Analysis (MDA) atau yang lebih dikenal dengan nama model Altman z-score. Dalam penelitian ini model Altman z-score yang digunakan adalah model Altman z-score modifikasi. Menurut Ramadhani dan Lukviarman (2009) model Altman modifikasi ini dapat digunakan pada semua perusahaan seperti manufaktur, non manufaktur, dan perusahaan penerbit obligasi di negara berkembang (emerging market). Ini karena dalam model Altman modifikasi variabel X5 (sales to total assets) dihilangkan, karena perusahaan non manufaktur tidak mempunyai akun sales (penjualan) dan mengganti X4 (market value of equity to book value of debt) menjadi book value of equity to book value of debt (nilai buku ekuitas terhadap total kewajiban), dikarenakan banyak industri yang belum listing di bursa saham sehingga belum mempunyai nilai pasar saham. 
Berdasarkan uraian di atas, maka analisis untuk mengetahui keadaan perbankan syariah yang mempunyai fungsi strategis dan menjadi urat nadi bagi perekonomian Indonesia sangat penting dan dibutuhkan. Mengetahui kondisi perbankan syariah apakah dalam keadaan sehat atau dalam keadaan yang berpotensi mengalami kebangkrutan menjadi hal yang utama. Karena bila keadaan buruk suatu bank dapat diketahui sejak awal, maka akan lebih mudah bagi pihak internal bank dan pemerintah menyelamatkan kondisi bank tersebut dari hal yang paling buruk yaitu kebangkrutan.

\section{METODE}

Penelitian ini menggunakan dua model analisis, yaitu metode RGEC dan model analisis Altman z-score modifikasi. Metode analisis RGEC berdasarkan Peraturan Otoritas Jasa Keuangan Nomor 8/P0JK.03/2014 Tentang Penilaian Tingkat Kesehatan Bank Umum Syariah dan Unit Usaha Syariah. Dalam analisis Altman z-score modifikasi ini Altman mengeliminasi variabel X5 (sales/total assets), karena rasio ini sangat bervariatif pada industri dengan ukuran aset yang berbeda-beda. Maka, formula persamaan z-score yang telah dimodifikasi oleh Altman dkk menunjukkan fungsi diskriminan sebagai berikut:

$$
Z=6.56 X_{1}+3.26 X_{2}+6.72 X_{3}+1.05 X_{4}
$$

Dimana:

$\mathrm{X}_{1}=$ net working capital to total assets

$\mathrm{X}_{2}=$ retained earning to total assets

$\mathrm{X}_{3}=$ earning before interest and tax tototal assets

$\mathrm{X}_{4}=$ book value of equity to book value of debt

$\mathrm{Z}=$ overall index

Klasifikasi perusahaan yang bangkrut, grey area dan tidak bangkrut didasarkan pada nilai $z$-score modifikasi adalah:

a. Nilai $Z<1,23$ dikategorikan perusahaan yang bangkrut. 
b. Nilai $1,23<\mathrm{Z}<2,90$ dikategorikan dalam grey area, perusahaan tersebut tidak dapat dikatakan bangkrut tapi juga tidak dapat dikatakan sehat.

c. Nilai Z > 2,90 dikategorikan perusahaan yang tidak bangkrut.

Dari 12 bank umum syariah, penelitian ini menggunakan 10 bank umum syariah saja sebagai sampel penelitian. Pemilihan 10 bank umum syariah ini didasarkan pada pertimbangan sebagai berikut:

1. Bank syariah yang dipilih adalah bank yang sudah berdiri menjadi bank umum syariah sejak tahun 2010-2014.

2. Bank umum syariah mempunyai kelengkapan data laporan keuangan yang telah di audit dan dipublikasikan dari tahun 2010-2014.

3. Bank umum syariah juga harus mempunyai kelengkapan laporan good corporate governance (GCG) untuk tahun 20102014.

Maka dari pertimbangan tersebut ada dua bank umum syariah yang tidak masuk untuk dijadikan sampel penelitian, yaitu Maybank Syariah dan BTPN Syariah.

\section{PEMBAHASAN}

Penilaian tingkat kesehatan pada bank umum syariah penting untuk dilakukan. Penting karena dari penilaian tingkat kesehatan bank maka akan diketahui bagaimana hasil dari kinerja bank umum syariah tersebut dalam kegiatan usahanya. Metode yang digunakan dalam menilai tingkat kesehatan bank umum syariah adalah metode RGEC. Berdasarkan penjelasan singkat tersebut, rasiorasio yang digunakan untuk mewakili metode RGEC dalam menilai tingkat kesehatan bank umum syariah adalah:

1. Risk Profile (profil risiko) untuk risiko inheren penilaiannya digambarkan melalui rasio NPF dan Liquidity Risk. Sedangkan untuk kualitas manajemen 
risikonya berdasarkan data yang ada dalam laporan tahunan dan GCG masing-masing bank umum syariah.

a. Non Performing Financing (NPF)

Tabel 1. Hasil NPF BUS Tahun 2010-2014 (dalam \%)

\begin{tabular}{rlccccc}
\hline No & $\begin{array}{c}\text { Bank Umum } \\
\text { Syariah }\end{array}$ & $\mathbf{2 0 1 0}$ & $\mathbf{2 0 1 1}$ & $\mathbf{2 0 1 2}$ & $\mathbf{2 0 1 3}$ & $\mathbf{2 0 1 4}$ \\
\hline & & 4.32 & 2.60 & 2.09 & 1.35 & 6.43 \\
1 & BMI & 0.00 & 2.43 & 3.19 & 3.71 & 7.10 \\
2 & BVS & 3.19 & 2.77 & 3.00 & 4.06 & 4.60 \\
3 & BRIS & 1.80 & 1.36 & 3.97 & 1.86 & 5.84 \\
4 & BJBS & 3.59 & 3.62 & 3.02 & 1.86 & 1.86 \\
5 & BNIS & 3.52 & 3.03 & 2.67 & 2.98 & 3.89 \\
6 & BMS & 0.00 & 0.88 & 0.20 & 1.20 & 0.53 \\
7 & BPS & 3.80 & 1.74 & 4.57 & 4.27 & 4.07 \\
8 & BSB & 3.52 & 2.42 & 2.82 & 4.32 & 6.84 \\
9 & BSM & 1.20 & 0.15 & 0.10 & 0.10 & 0.12 \\
10 & BCAS & & & &
\end{tabular}

Sumber: data diolah

Data pada Tabel 1 menunjukkan tahun 2010 rasio NPF tertinggi ada pada Bank Muamalat Indonesia dengan nilai 4.32\%, artinya dari total pembiayaan yang disalurkan oleh Bank Muamalat Indonesia sebesar $4.32 \%$ adalah pembiayaan bermasalah. Rasio NPF terendah ada pada Bank Victoria Syariah dan Bank Panin Syariah dengan nilai $0.00 \%$. Nilai ini dikarenakan kedua bank baru berdiri sehingga penyaluran pembiayaan yang dilakukan belum terlalu banyak, hal ini mengakibatkan jumlah pembiayaan yang bermasalah pada bank tersebut di tahun 2010 belum ada.

Tahun 2011-2013 nilai rasio NPF berfluktuasi pada setiap BUS dan nilai rasio ini tetap berada di bawah $8 \%$. Peningkatan nilai rasio NPF terjadi tahun 2014 dari 10 bank umum syariah 7 diantaranya mengalami peningkatan dari tahun 2013. Hanya BNI syariah yang pada tahun 2014 mempunyai nilai NPF sama seperti tahun sebelumnya, sedangkan Bank Panin Syariah dan Bank Syariah Bukopin nilai rasionya mengalami penurunan dari tahun sebelumnya. Semakin rendah nilai rasio ini memberikan indikasi bahwa bank umum syariah semakin baik meminimalkan risiko gagal bayar dan berakibat pula meningkatkan laba bank tersebut. 


\section{b. Liquidity Risk (LR)}

Tabel 2. Hasil Liqudity Risk BUS Tahun 2010-2014 (dalam \%)

\begin{tabular}{|c|c|c|c|c|c|c|}
\hline \multirow{2}{*}{ No } & \multirow{2}{*}{$\begin{array}{l}\text { Bank Umum } \\
\text { Syariah }\end{array}$} & \multicolumn{5}{|c|}{ Tahun } \\
\hline & & 2010 & 2011 & 2012 & 2013 & 2014 \\
\hline 1 & BMI & 9.40 & 21.53 & 8.37 & 3.61 & 12.26 \\
\hline 2 & BVS & 15.91 & 55.16 & 33.41 & 19.68 & 10.65 \\
\hline 3 & BRIS & 10.48 & 9.87 & 16.16 & 15.24 & 31.47 \\
\hline 4 & BJBS & 11.32 & 38.37 & 28.21 & 17.62 & 21.55 \\
\hline 5 & BNIS & 19.52 & 23.00 & 0.89 & 2.92 & 5.70 \\
\hline 6 & BMS & 12.64 & 4.36 & 1.30 & 10.60 & 10.60 \\
\hline 7 & BPS & 42.98 & 52.23 & 26.56 & 41.07 & 16.87 \\
\hline 8 & BSB & 19.90 & 20.79 & 19.51 & 14.69 & 23.20 \\
\hline 9 & BSM & 10.48 & 7.05 & 0.96 & 3.90 & 13.65 \\
\hline 10 & BCAS & 18.41 & 20.89 & 18.00 & 19.96 & 25.97 \\
\hline
\end{tabular}

Sumber: data diolah

Hasil perhitungan pada Tabel 2 menunjukkan rasio likuiditas yang dimiliki bank umum syariah tahun 2010 dapat dikatakan cukup baik karena semua nilai rasio BUS di atas 5\%. Tahun 2011 juga dapat dikatakan bahwa kondisi likuiditas bank umum syariah cukup baik, hanya Bank Syariah Mega yang rasio likuiditasnya di bawah 5\% sehingga dikatakan kurang baik. Tahun 2012 ada tiga bank yang rasio likuiditasnya kurang dari 5\% yaitu BNI Syariah, Bank Syariah Mega dan Bank Syariah Mandiri. Tahun 2013 juga ada tiga bank yang nilai rasionya di bawah 5\% yaitu Bank Muamalat Indonesia, BNI Syariah dan Bank Syariah Mandiri, sedangkan di tahun 2013 seluruh bank umum syariah mempunyai rasio lebih dari 5\%. Dari hasil peringkat komponen profil risiko (risk profile) bank umum syariah tahun 2010 sampai tahun $2014 \mathrm{di}$ atas, maka diperoleh nilai komposit untuk faktor profil risiko. Nilai komposit profil risiko untuk masing-masing bank umum syariah tahun 20102014 adalah: 
Tabel 3. Peringkat Seluruh Komponen Profil Risiko BUS Tahun 2010-2014

\begin{tabular}{|c|c|c|c|c|c|c|c|c|c|c|c|}
\hline \multirow{3}{*}{ No } & \multirow{3}{*}{$\begin{array}{c}\text { Bank } \\
\text { Umum } \\
\text { Syariah }\end{array}$} & \multicolumn{10}{|c|}{ Tahun } \\
\hline & & \multicolumn{2}{|c|}{2010} & \multicolumn{2}{|c|}{2011} & \multicolumn{2}{|c|}{2012} & \multicolumn{2}{|c|}{2013} & \multicolumn{2}{|c|}{2014} \\
\hline & & RI & KPM & RI & KPM & RI & KPM & RI & KPM & RI & KPM \\
\hline 1 & BMI & LtM & Sa & $\mathrm{L}$ & $\mathrm{Sa}$ & LtM & $\mathrm{Sa}$ & $\mathrm{M}$ & $\mathrm{Sa}$ & M & $\mathrm{Sa}$ \\
\hline 2 & BVS & $\mathrm{L}$ & Sa & $\mathrm{L}$ & $\mathrm{Sa}$ & $\mathrm{L}$ & $\mathrm{Sa}$ & LtM & $\mathrm{Sa}$ & M & Sa \\
\hline 3 & BRIS & LtM & S & LtM & $\mathrm{Sa}$ & LtM & $\mathrm{Sa}$ & LtM & $\mathrm{Sa}$ & LtM & Sa \\
\hline 4 & BJBS & LtM & $\mathrm{Fa}$ & $\mathrm{L}$ & $\mathrm{Fa}$ & $\mathrm{L}$ & $\mathrm{Fa}$ & LtM & $\mathrm{Fa}$ & LtM & Sa \\
\hline 5 & BNIS & LtM & Sa & LtM & $\mathrm{Sa}$ & $\mathrm{L}$ & $\mathrm{S}$ & LtM & $\mathrm{Sa}$ & LtM & Sa \\
\hline 6 & BMS & LtM & Sa & M & $\mathrm{Sa}$ & M & Sa & LtM & $\mathrm{Sa}$ & LtM & Sa \\
\hline 7 & BPS & $\mathrm{L}$ & $\mathrm{Fa}$ & $\mathrm{L}$ & $\mathrm{Fa}$ & $\mathrm{L}$ & $\mathrm{S}$ & L & $\mathrm{S}$ & LtM & S \\
\hline 8 & BSB & LtM & Sa & $\mathrm{L}$ & $\mathrm{Sa}$ & $\mathrm{L}$ & $\mathrm{Sa}$ & LtM & $\mathrm{Sa}$ & LtM & Sa \\
\hline 9 & BSM & LtM & Sa & LtM & $\mathrm{Sa}$ & M & $\mathrm{Sa}$ & M & $\mathrm{Sa}$ & M & Sa \\
\hline 10 & BCAS & $\mathrm{L}$ & Sa & $\mathrm{L}$ & $\mathrm{Sa}$ & $\mathrm{L}$ & Sa & L & Sa & $\mathrm{L}$ & Sa \\
\hline
\end{tabular}

Sumber: data olahan, laporan keuangan tahunan dan laporan GCG

Dimana:

$$
\begin{array}{llll}
\mathrm{RI} & =\text { Risiko Inheren } & \mathrm{KPM} & =\text { Kualitas Penerapan Manajemen } \\
\mathrm{L} & =\text { Low } & \mathrm{LtM} & =\text { Low to Moderate } \\
\mathrm{M} & =\text { Moderate } & \mathrm{S} & =\text { Strong } \\
\mathrm{Sa} & =\text { Satisfactory } & \mathrm{Fa} & =\text { Fair }
\end{array}
$$

Berdasarkan hasil penilaian profil risiko bank umum syariah tahun 2010 untuk penilaian terhadap rata-rata risiko inheren adalah Low to Moderate dengan kualitas penerapan manajemen adalah Satisfactory. Ini menandakan bahwa risiko kerugian atas aktivitas usaha yang dilakukan BUS dinilai rendah, karena kualitas penerapan manajemen risiko yang diterapkan oleh bank umum syariah baik.

Untuk tahun 2011 dan 2012 penilaian terhadap profil risiko menunjukkan, risiko inheren bank umum syariah adalah Low dengan kualitas penerapan manajemen risiko Satisfactory, artinya adalah risiko kerugian atas aktivitas usaha yang dilakukan bank umum syariah dinilai sangat rendah, karena kualitas manajemen risiko diterapkan dengan baik oleh bank umum syariah. Pada tahun 2013 dan 2014, hasilnya cenderung sama dengan profil risiko tahun 2010.

2. Good Corporate Governance (GCG), untuk faktor ini akan dinilai berdasarkan nilai komposit dari hasil self assessment yang dilakukan oleh bank umum syariah dan kemudian dipublikasikan melalui laporan GCG masing- 
masing bank umum syariah tahun 2010-2014 yang telah dipublikasikan.

Tabel 4. Hasil dan Peringkat GCG Bank Umum Syariah

\begin{tabular}{|c|c|c|c|c|c|c|c|c|c|c|c|}
\hline \multirow[t]{2}{*}{ No } & \multirow{2}{*}{$\begin{array}{c}\text { Bank } \\
\text { Umum } \\
\text { Syariah }\end{array}$} & \multicolumn{2}{|c|}{2010} & \multicolumn{2}{|c|}{2011} & 2012 & & \multicolumn{2}{|c|}{2013} & \multicolumn{2}{|c|}{2014} \\
\hline & & NK & Ket & NK & Ket & NK & Ket & NK & Ket & NK & Ket \\
\hline 1 & BMI & 1.4 & B & 1.3 & B & 1.7 & B & 1.15 & SB & 2.5 & CB \\
\hline 2 & BVS & 1.75 & B & 1.69 & B & 2.07 & B & 1.66 & B & 1.93 & B \\
\hline 3 & BRIS & 1.61 & B & 1.55 & B & 1.38 & SB & 1.35 & SB & 1.74 & B \\
\hline 4 & BJBS & 1.5 & B & 1.6 & B & 2.53 & B & 1.78 & B & 2 & B \\
\hline 5 & BNIS & 1.625 & B & 1.3 & B & 1.315 & B & 1.3 & B & 2.12 & B \\
\hline 6 & BMS & 1.875 & B & 1.825 & B & 1.6 & B & 1.869 & B & 2 & B \\
\hline 7 & BPS & 2.2 & B & 1.95 & B & 1.35 & SB & 1.35 & SB & 1.45 & B \\
\hline 8 & BSB & 1.6 & B & 1.6 & B & 1.5 & B & 1.5 & B & 2 & B \\
\hline 9 & BSM & 1.35 & SB & 2.35 & B & 1.675 & B & 1.85 & B & 2.12 & B \\
\hline 10 & BCAS & 2.1 & B & 1.9 & B & 1.8 & B & 1.55 & B & 1 & SB \\
\hline
\end{tabular}

Sumber: data diolah dari laporan GCG BUS 2010-2014

Dimana:

$$
\begin{array}{llll}
\mathrm{NK} & =\text { Nilai Komposit } & \mathrm{SB} & =\text { Sangat Baik } \\
\mathrm{B} & =\text { Baik } & \mathrm{CB} & =\text { Cukup Baik }
\end{array}
$$

Berdasarkan penilaian terhadap penerapan GCG didapatkan hasil bahwa nilai komposit GCG rata-rata bank umum syariah tahun 2010-2014 masuk ke dalam peringkat yang baik, karena indeks nilai komposit penerapan GCG bank umum syariah masih di bawah 2.5, artinya kelemahan dalam penerapan GCG secara umum tidak terlalu berpengaruh pada kegiatan usaha bank umum syariah dan kelemahan tersebut dapat diselesaikan dengan tindakan normal oleh manajemen bank. Syarat untuk dikatakan GCG dalam peringkat yang baik adalah bila nilai komposit (NK) bank umum syariah lebih besar dari 1.5 tapi nilai komposit juga tidak boleh lebih dari 2.5 atau bisa ditulis $(1.5 \leq \mathrm{NK} \geq 2.5)$.

3. Earning (Rentabilitas) untuk mencerminkan hasil penilaian rentabilitas (earning) bank umum syariah, maka peneliti menggunakan rasio Return On Asset (ROA) dan Net Core Operation Margin (NCOM) 
a. Return On Asset (ROA)

Tabel 5. Hasil ROA Bank Umum Syariah (dalam \%)

\begin{tabular}{rlrrrrr}
\hline No & \multicolumn{2}{c}{$\begin{array}{c}\text { Bank Umum } \\
\text { Syariah }\end{array}$} & \multicolumn{2}{c}{ Tahun } \\
\\
& BMI & $\mathbf{2 0 1 0}$ & $\mathbf{2 0 1 1}$ & $\mathbf{2 0 1 2}$ & $\mathbf{2 0 1 3}$ & \multicolumn{1}{c}{$\mathbf{2 0 1 4}$} \\
\hline 2 & BVS & 1.08 & 1.14 & 1.16 & 1.20 & 0.15 \\
3 & BRIS & 0.89 & 4.08 & 1.08 & 0.37 & $(1.74)$ \\
4 & BJBS & 0.26 & 0.15 & 0.98 & 1.06 & 0.15 \\
5 & BNIS & 0.4 & 0.94 & 0.49 & 0.40 & 0.49 \\
6 & BMS & 0.57 & 1.06 & 1.29 & 1.22 & 1.13 \\
7 & BPS & 1.82 & 1.29 & 3.02 & 2.15 & 0.33 \\
8 & BSB & $(1.56)$ & 1.20 & 2.32 & 0.72 & 1.54 \\
9 & BSM & 0.68 & 0.55 & 2.08 & 0.63 & 0.25 \\
10 & BCAS & 1.80 & 1.57 & 2.08 & 1.42 & 0.17 \\
\hline Sumber & 0.72 & 0.73 & 0.68 & 0.82 & 0.66 \\
\hline
\end{tabular}

Sumber: data diolah

Berdasarkan penilaian rentabilitas dari sisi ROA pada tahun 2010 nilai rasio tertinggi ada pada Bank Syariah Mega dengan nilai 1.82 dan nilai rasio terendah ada pada Bank Panin Syariah karena bernilai -1.56, nilai minus yang dihasilkan karena pendapatan yang diterima oleh bank tersebut lebih kecil dari beban yang harus dibayar. Pada tahun 2011 nilai rasio ROA tertinggi ada pada Bank Victoria Syariah, tahun 2012 dan 2013 rasio ROA tertinggi ada pada Bank Syariah Mega. Tahun 2014 rasio tertinggi ada pada Bank Panin Syariah dan rasio terendah ada pada Bank Victoria Syariah dengan nilai -1.74. Bank umum syariah dikategorikan mempunyai ROA yang baik jika nilai ROA berada di atas $1.5 \%$

Jika dilihat dari data pada tabel di atas, nilai rasio ROA yang dihasilkan oleh rata-rata BUS masih tergolong rendah, padahal semakin tinggi nilai rasio ini berpotensi semakin besar bank umum syariah dalam menghasilkan pendapatan dari pengelolaaan aktiva yang dimiliki. Selama kurun waktu lima tahun terakhir rasio ROA tertinggi ada pada tahun 2011 yaitu Bank Victoria Syariah dengan nilai 4.08, artinya Bank Victoria Syariah mampu menghasilkan pendapatan sebesar $4.08 \%$ dari total aktiva yang digunakannya. 
b. Net Core Operation Margin (NCOM)

Tabel 6. Hasil NCOM Bank Umum Syariah (dalam \%)

\begin{tabular}{rlrrrrr}
\hline No & \multicolumn{2}{c}{ Bank Umum } & \multicolumn{5}{c}{ Tahun } \\
& Syariah & $\mathbf{2 0 1 0}$ & $\mathbf{2 0 1 1}$ & $\mathbf{2 0 1 2}$ & $\mathbf{2 0 1 3}$ & $\mathbf{2 0 1 4}$ \\
1 & BMI & 8.09 & 7.46 & 6.92 & 8.93 & 8.72 \\
2 & BVS & 6.82 & 4.98 & 8.10 & 8.11 & 10.34 \\
3 & BRIS & 10.49 & 10.01 & 10.01 & 10.61 & 6.79 \\
4 & BJBS & 5.93 & 9.07 & 8.77 & 11.42 & 10.18 \\
5 & BNIS & 6.94 & 12.9 & 12.97 & 9.83 & 11.09 \\
6 & BMS & 21.34 & 17.33 & 15.28 & 16.21 & 18.88 \\
7 & BPS & 5.05 & 7.16 & 6.93 & 6.81 & 8.57 \\
8 & BSB & 10.38 & 8.87 & 8.68 & 9.26 & 9.75 \\
9 & BSM & 9.37 & 8.84 & 9.71 & 9.71 & 9.47 \\
10 & BCAS & 16.64 & 6.62 & 10.29 & 9.60 & 9.13 \\
\hline
\end{tabular}

Sumber: data diolah

Data pada Tabel 6 menunjukkan rasio NCOM bank umum syariah tahun 2010-2014 seluruhnya berada di atas 3\%. Maka dapat dikatakan bahwa rasio NCOM ini sangat baik. Semakin tinggi nilai dari rasio ini menunjukkan kinerja bank umum syariah dalam mengelola aktiva produktif untuk menghasilkan laba sangat baik. Nilai rasio NCOM dalam kurun waktu 2010-2014 dimiliki oleh Bank Syariah Mega. Nilai rasio tertinggi NCOM yang dimiliki Bank Syariah Mega ada pada tahun 2010 dengan nilai 21.34\%. Artinya Bank Syariah Mega dapat menghasilkan pendapatan sebesar $21.34 \%$ dari total aktiva produktif yang digunakannya.

4. Capital (Modal), untuk menggambarkan keadaan dari modal ini, maka peneliti menggunakan Current Asset Ratio (CAR) dalam perhitungannya. Rasio CAR yang dimiliki oleh bank umum syariah periode 2010-2014 ditunjukkan pada tabel 7.

Penilaian permodalan pada bank umum syariah memberikan hasil bahwa seluruh rasio CAR memiliki nilai di atas 8\%. Nilai ini merupakan nilai kewajiban minimum permodalan bank yang telah ditetapkan oleh Bank Indonesia dan harus dipenuhi oleh seluruh Bank yan ada di Indonesia. Semakin tinggi nilai rasio CAR menunjukkan potensi modal bank yang semakin kuat untuk mengcover segala hal buruk yang mungkin terjadi pada bank tersebut. Jika dilihat dari tahun 2010-2014 rata-rata nilai rasio CAR bank umum syariah dalam keadaan yang sangat baik, karena nilai rasio CAR yang dimiliki di atas 
11\%. Nilai CAR tertinggi dalam waktu lima tahun terakhir dimiliki oleh BCA Syaria dengan nilai 76,39. Artinya kemampuan permodalan BCA Syariah sangat baik, sehingga dapat membantu kegiatan aktivitas operasional bank tersebut dalam meningkatkan laba.

Tabel 7. Hasil CAR Bank Umum Syariah (dalam \%)

\begin{tabular}{|c|c|c|c|c|c|c|}
\hline \multirow{2}{*}{ No } & \multirow{2}{*}{ Bank } & \multicolumn{5}{|c|}{ Tahun } \\
\hline & & 2010 & 2011 & 2012 & 2013 & 2014 \\
\hline 1 & BMI & 13.56 & 12.01 & 11.72 & 14.18 & 14.22 \\
\hline 2 & BVS & 18.70 & 45.22 & 28.09 & 18.40 & 15.28 \\
\hline 3 & BRIS & 20.62 & 14.74 & 11.35 & 14.49 & 13.03 \\
\hline 4 & BJBS & 31.43 & 30.28 & 21.73 & 17.99 & 15.78 \\
\hline 5 & BNIS & 27.68 & 20.75 & 14.10 & 16.23 & 18.42 \\
\hline 6 & BMS & 13.14 & 12.03 & 12.03 & 13.51 & 25.69 \\
\hline 7 & BPS & 54.81 & 56.97 & 32.20 & 20.69 & 18.82 \\
\hline 8 & BSB & 11.51 & 15.29 & 12.78 & 11.10 & 15.85 \\
\hline 9 & BSM & 10.60 & 14.57 & 13.88 & 13.82 & 14.10 \\
\hline 10 & BCAS & 76.39 & 45.94 & 31.47 & 22.35 & 29.57 \\
\hline
\end{tabular}

Sumber: data diolah

Jadi berdasarkan hasil penilaian keseluruhan kesehatan bank umum syariah dengan menggunakan metode RGEC di atas selama periode 2010 sampai dengan 2014, didapatkan peringkat komposit untuk mengetahui tingkat kesehatan bank syariah. Peringkat komposit (PK) untuk masing-masing bank umum syariah sebagaimana pada Tabel 8.

Tabel 8. Peringkat Komposit BUS Metode RGEC Tahun 2010-2014

\begin{tabular}{|c|c|c|c|c|c|c|c|c|c|c|c|}
\hline \multirow{3}{*}{ No } & \multirow{3}{*}{$\begin{array}{l}\text { Nama } \\
\text { Bank }\end{array}$} & \multicolumn{10}{|c|}{ Tahun } \\
\hline & & \multicolumn{2}{|c|}{2010} & \multicolumn{2}{|c|}{2011} & \multicolumn{2}{|c|}{2012} & \multicolumn{2}{|c|}{2013} & \multicolumn{2}{|c|}{2014} \\
\hline & & PK & Ket & PK & Ket & PK & Ket & PK & Ket & PK & Ket \\
\hline 1 & BMI & 2 & SEHAT & 2 & SEHAT & 2 & SEHAT & 2 & SEHAT & 2 & SEHAT \\
\hline 2 & BVS & 2 & SEHAT & 2 & SEHAT & 2 & SEHAT & 2 & SEHAT & 2 & SEHAT \\
\hline 3 & BRIS & 2 & SEHAT & 2 & SEHAT & 2 & SEHAT & 2 & SEHAT & 2 & SEHAT \\
\hline 4 & BJBS & 2 & SEHAT & 2 & SEHAT & 2 & SEHAT & 2 & SEHAT & 2 & SEHAT \\
\hline 5 & BNIS & 2 & SEHAT & 2 & SEHAT & 2 & SEHAT & 2 & SEHAT & 2 & SEHAT \\
\hline 6 & BMS & 2 & SEHAT & 2 & SEHAT & 2 & SEHAT & 2 & SEHAT & 2 & SEHAT \\
\hline 7 & BPS & 2 & SEHAT & 2 & SEHAT & 2 & SEHAT & 2 & SEHAT & 2 & SEHAT \\
\hline 8 & BSB & 2 & SEHAT & 2 & SEHAT & 2 & SEHAT & 2 & SEHAT & 2 & SEHAT \\
\hline 9 & BSM & 2 & SEHAT & 2 & SEHAT & 2 & SEHAT & 2 & SEHAT & 2 & SEHAT \\
\hline 10 & BCAS & 2 & SEHAT & 2 & SEHAT & 2 & SEHAT & 2 & SEHAT & 2 & SEHAT \\
\hline
\end{tabular}

Sumber: data diolah, Keterangan $P K=$ Peringkat Komposit

Hasil pada Tabel 8. menunjukkan bahwa dari tahun 2010-2014 penilaian tingkat kesehatan bank umum syariah menggunakan metode RGEC yang diwakili oleh beberapa rasio keuangan menunjukkan bahwa bank umum 
syariah ada pada kategori "sehat" (PK-2). Kategori sehat ini maksudnya adalah bank umum syariah tergolong baik dan mampu mengatasi pengaruh negatif kondisi perekonomian dan mampu juga mengatasi perubahan lingkungan bisnis di industri keuangan.

\section{Penilaian Potensi Kebangkrutan Bank Umum Syariah}

Setelah mengetahui tingkat kesehatan bank, maka selanjutnya adalah melakukan penilaian potensi kebangkrutan pada bank umum syariah. Penilaian dilakukan dengan menggunakan model Altman z-score modifikasi, yaitu suatu model analisis diskriminan alternatif yang dikembangkan oleh Altman dan untuk perhitungannya membutuhkan empat rasio keuangan yang menjadi variabel. Untuk menentukan nilai $\mathrm{z}$ dan mengkategorikan nilai tersebut ke dalam kelompok yang telah ditentukan maka yang dilakukan adalah menghitung rasio keuangan yang ada dalam model Altman z-score modifikasi. Rasio-rasio tersebut adalah:

1. $\mathrm{X}_{1}=$ Net Working Capital to Total Assets

Berdasarkan perhitungan menggunakan rasio net working capital to total asset (modal kerja bersih terhadap total aktiva), maka modal kerja bersih yang dimiliki oleh BUS menunjukkan nilai:

\section{Tabel 9. Modal Kerja Bersih (Net Working Capital) -dalam jutaan rupiah}

\begin{tabular}{|c|c|c|c|c|c|c|}
\hline \multirow{2}{*}{ No. } & \multirow{2}{*}{$\begin{array}{c}\text { Bank } \\
\text { Umum } \\
\text { Syariah }\end{array}$} & \multirow[b]{2}{*}{2010} & \multicolumn{4}{|c|}{ Tahun } \\
\hline & & & 2011 & 2012 & 2013 & 2014 \\
\hline 1 & BMI & $17,413,059$ & $27,346,655$ & $35,581,638$ & $43,042,812$ & $49,357,049$ \\
\hline 2 & BVS & 279,069 & 562,460 & 755,946 & $1,189,466$ & $1,320,881$ \\
\hline 3 & BRIS & $5,600,431$ & $8,870,680$ & $10,773,980$ & $12,929,302$ & $16,103,478$ \\
\hline 4 & BJBS & $1,677,371$ & $2,849,451$ & $3,605,195$ & $3,846,871$ & $5,375,024$ \\
\hline 5 & BNIS & $5,582,595$ & $6,742,492$ & $8,322,660$ & $10,556,072$ & $15,799,167$ \\
\hline 6 & BMS & $3,170,174$ & $3,715,521$ & $6,061,809$ & $7,235,246$ & $5,461,262$ \\
\hline 7 & BPS & 408,741 & 827,504 & $1,321,221$ & $2,992,961$ & $5,280,680$ \\
\hline 8 & BSB & $1,447,029$ & $2,125,127$ & $26,191,911$ & $3,040,519$ & $3,921,853$ \\
\hline 9 & BSM & $26,105,801$ & $40,859,935$ & $44,058,321$ & $50,445,953$ & $56,104,646$ \\
\hline 10 & BCAS & 763,140 & $1,027,175$ & $1,334,159$ & $1,750,291$ & $2,653,175$ \\
\hline
\end{tabular}

Setelah diketahui nilai modal kerja bersih yang dimiliki oleh BUS selama periode 2010-2014, maka selanjutnya hal yang harus diketahui adalah nilai total aktiva dari bank umum syariah periode 2010-2014. Maka nilai untuk 
total aktiva yang dimiliki oleh bank umum syariah (BUS) ditunjukkan pada tabel di bawah ini:

Tabel 10. Total Aktiva (Total Assets) -dalam jutaan rupiah

\begin{tabular}{rlrrrrr}
\hline No. & $\begin{array}{l}\text { Bank Umum } \\
\text { Syariah }\end{array}$ & \multicolumn{6}{c}{ Tahun } \\
& & $\mathbf{2 0 1 0}$ & \multicolumn{1}{c}{$\mathbf{2 0 1 1}$} & \multicolumn{1}{c}{$\mathbf{2 0 1 2}$} & \multicolumn{1}{c}{$\mathbf{2 0 1 3}$} & \multicolumn{1}{c}{$\mathbf{2 0 1 4}$} \\
\hline 1 & BMI & $21,442,596$ & $32,479,506$ & $44,854,413$ & $54,694,020$ & $62,413,310$ \\
2 & BVS & 336,676 & 642,026 & 939,472 & $1,323,398$ & $1,439,903$ \\
3 & BRIS & $6,856,386$ & $11,200,823$ & $14,088,914$ & $17,400,914$ & $20,356,863$ \\
4 & BJBS & $1,930,469$ & $2,749,451$ & $4,275,097$ & $4,695,088$ & $6,090,945$ \\
5 & BNIS & $6,394,924$ & $8,466,887$ & $10,645,313$ & $14,708,504$ & $19,492,112$ \\
6 & BMS & $4,637,730$ & $5,565,724$ & $8,164,921$ & $9,121,575$ & $7,042,489$ \\
7 & BPS & 458,713 & $1,016,878$ & $2,140,482$ & $4,052,701$ & $6,207,679$ \\
8 & BSB & $2,193,952$ & $2,730,027$ & $3,616,108$ & $4,343,069$ & $5,161,300$ \\
9 & BSM & $32,481,873$ & $48,671,950$ & $54,058,321$ & $63,965,361$ & $66,942,422$ \\
10 & BCAS & 874,631 & $1,217,097$ & $1,602,181$ & $2,041,419$ & $2,665,416$ \\
\hline
\end{tabular}

Sumber: data diolah

Dari tabel 10, kemudian dimasukkan ke dalam rumus:

$\mathrm{X}_{1}=$ Net Working Capital to Total Assets $=$ Asset Lancar - Kewajiban Lancar

Total Aktiva

Penggunaan rumus tersebut dimaksudkan untuk menghasilkan nilai rasio net working capital to total assets untuk bank umum syariah tahun 2010-2014. Tabel 11 akan menunjukkan nilai rasio net working capital to total asset bank umum syariah tahun 2010-2014.

Data pada Tabel 11 menunjukkan bahwa nilai rasio net working capital to total assets bank umum syariah selama kurun waktu lima tahun terakhir menunjukkan nilai yang cenderung stabil. Hal ini menunjukkan bahwa kemampuan bank umum syariah dalam menghasilkan modal kerja bersih sama pada setiap bank. Jumlah atau nilai yang modal kerja bersih yang dihasilkan dari penggunaan aktiva yang dimiliki oleh bank umum syariah tersebut setiap tahunnya juga hampir sama. 
Tabel 11. Hasil Net Working Capital to Total Assets (X1)

\begin{tabular}{rlrrrrr}
\hline \multirow{2}{*}{ No. } & Bank Umum Syariah & $\mathbf{2 0 1 0}$ & $\mathbf{2 0 1 1}$ & $\mathbf{2 0 1 2}$ & $\mathbf{2 0 1 3}$ & $\mathbf{2 0 1 4}$ \\
\hline 1 & BMI & 0.81 & 0.84 & 0.80 & 0.79 & 0.79 \\
2 & BVS & 0.83 & 0.88 & 0.80 & 0.90 & 0.92 \\
3 & BRIS & 0.82 & 0.79 & 0.76 & 0.74 & 0.79 \\
4 & BJBS & 0.87 & 0.89 & 0.84 & 0.82 & 0.88 \\
5 & BNIS & 0.87 & 0.80 & 0.78 & 0.72 & 0.81 \\
6 & BMS & 0.68 & 0.67 & 0.74 & 0.75 & 0.78 \\
7 & BPS & 0.89 & 0.81 & 0.62 & 0.74 & 0.85 \\
8 & BSB & 0.66 & 0.78 & 0.72 & 0.70 & 0.76 \\
9 & BSM & 0.80 & 0.84 & 0.82 & 0.79 & 0.84 \\
10 & BCAS & 0.87 & 0.84 & 0.83 & 0.86 & 0.89 \\
\hline
\end{tabular}

Sumber: data diolah

Semakin tinggi nilai rasio ini menunjukkan bank umum syariah semakin baik bank syariah menghasilkan modal kerja bersih yang berakibat semakin tinggi pula tingkat likuiditas bank tersebut. Berdasarkan hal ini maka dapat dilihat bahwa bank umum syariah yang tingkat likuiditasnya sangat baik selama kurun waktu lima tahun terakhir adalah Bank Victoria Syariah pada tahun 2012 dengan nilai 0.92. Artinya setiap pemakaian Rp 1 aktiva yang dimiliki Bank Victoria Syariah akan menghasilkan modal kerja bersih sebesar Rp 0.92 .

2. $\mathrm{X}_{2}=$ Retained Earning to Total Asset

Tabel 12 menunjukkan jumlah laba ditahan yang dimiliki perusahaan bank umum syariah selama lima tahun terakhir.

Tabel 12. Laba Ditahan (Retained Earning) -jutaan rupiah

\begin{tabular}{rlrrrrr}
\hline & \multicolumn{1}{c}{ Bank } & \multicolumn{5}{c}{ Tahun } \\
No. & $\begin{array}{c}\text { Umum } \\
\text { Syariah }\end{array}$ & \multicolumn{1}{c}{$\mathbf{2 0 1 0}$} & \multicolumn{1}{c}{$\mathbf{2 0 1 1}$} & \multicolumn{1}{c}{$\mathbf{2 0 1 2}$} & \multicolumn{1}{c}{$\mathbf{2 0 1 3}$} & \multicolumn{1}{c}{$\mathbf{2 0 1 4}$} \\
\hline 1 & BMI & 443,684 & 670,639 & $1,596,742$ & $1,120,895$ & 684,634 \\
2 & BVS & 0 & 2,655 & 23,214 & 33,378 & 37,453 \\
3 & BRIS & $(23,978)$ & $(12,324)$ & 89,564 & 219,128 & 228,343 \\
4 & BJBS & 5,393 & 20,579 & 30,095 & 40,571 & 35,531 \\
5 & BNIS & 36,512 & 72,386 & 186,218 & 303,680 & 448,500 \\
6 & BMS & 62,854 & 116,721 & 301,539 & 149,540 & 17,396 \\
7 & BPS & $(8,882)$ & 351 & 39,405 & 25,995 & 96,934 \\
8 & BSB & $(206,805)$ & $(194,596)$ & $(177,296)$ & $(157,750)$ & $(149,088)$ \\
9 & BSM & $1,358,882$ & $1,909,952$ & $2,772,182$ & $3,373,423$ & $3,445,201$ \\
10 & BCAS & 3,826 & 10,599 & 18,959 & 31,659 & 44,609 \\
\hline
\end{tabular}

Sumber: data diolah

Bila dilihat nilai laba ditahan untuk BRI Syariah, Bank Syariah Bukopin dan Bank Panin Syariah bernilai minus, ini dikarenakan adanya kesalahan 
kebijakan dalam pembagian deviden. Kesalahan ini berupa pembagian nilai deviden kepada pemegang saham lebih besar daripada nilai laba ditahan bank tersebut. Sedangkan Bank Victoria Syariah mempunyai nilai 0 karena bank tersebut baru beroperasi secara penuh sebagai bank umum syariah pada tahun 2010 sehingga belum mempunyai nilai laba ditahan. Dari tabel laba ditahan yang telah dibahas sebelumnya, kemudian dimasukkan ke dalam rumus:

$\mathrm{X}_{2}=$ Retainde Earning to Total assets $=\quad$ Laba Ditahan

Total Aktiva

Maka, dari penggunaan rumus tersebut dihasilkan nilai rasio retained earnings to total assets (laba ditahan terhadap total aktiva) untuk bank umum syariah selama tahun 2010-2014. Nilai rasio yang didapat kemudian dituangkan dalam Tabel 13.

Tabel 13. Hasil Retained Earning to Total Assets (X2)

\begin{tabular}{|c|c|c|c|c|c|c|}
\hline \multirow{2}{*}{ No. } & \multirow{2}{*}{$\begin{array}{c}\text { Bank Umum } \\
\text { Syariah }\end{array}$} & \multicolumn{5}{|c|}{ Tahun } \\
\hline & & 2010 & 2011 & 2012 & 2013 & 2014 \\
\hline 1 & BMI & 0.021 & 0.021 & 0.036 & 0.020 & 0.011 \\
\hline 2 & BVS & 0 & 0.041 & 0.025 & 0.025 & 0.026 \\
\hline 3 & BRIS & $(0.0035)$ & $(0.0011)$ & $(0.00087)$ & 0.0051 & 0.011 \\
\hline 4 & BJBS & 0.003 & 0.007 & 0.005 & 0.009 & 0.006 \\
\hline 5 & BNIS & 0.006 & 0.009 & 0.017 & 0.021 & 0.023 \\
\hline 6 & BMS & 0.014 & 0.021 & 0.037 & 0.016 & 0.0025 \\
\hline 7 & BPS & $(0.018)$ & 0.00035 & 0.018 & 0.006 & 0.016 \\
\hline 8 & BSB & $(0.094)$ & $(0.071)$ & $(0.049)$ & $(0.036)$ & (0.028) \\
\hline 9 & BSM & 0.042 & 0.039 & 0.051 & 0.053 & 0.051 \\
\hline 10 & BCAS & 0.004 & 0.009 & 0.012 & 0.016 & 0.017 \\
\hline
\end{tabular}

Sumber: data diolah

Data pada Tabel 13 memperlihatkan bahwa perkembangan nilai rasio ini selama kurun waktu lima tahun terakhir pada setiap bank umum syariah menunjukkan nilai yang kecil cenderung konsisten. Selain itu dapat dilihat bahwa ada beberapa bank yang mempunyai nilai rasio negatif, yaitu Bank Syariah Bukopin yang dari tahun 2010 sampai tahun 2014 tetap mempunyai nilai yang minus. Hal yang sama juga terjadi pada BRI Syariah yang mengalami nilai minus dari tahun 2010-2012, tapi di tahun selanjutnya yaitu 2013 dan 2014 nilai rasio retained earnings to total assets BRI syariah mulai membaik dengan mendapatkan hasil yang positif. Bank Panin Syariah juga pada tahun 
2010 nilai rasionya negatif, tapi di tahun-tahun selanjutnya mulai menunjukkan nilai yang positif. Hasil rasio ini bisa bernilai minus karena nilai dari laba ditahan yang dimiliki oleh bank tersebut juga minus.

Semakin tinggi nilai rasio ini menunjukkan indikasi laba ditahan yang dihasilkan bank umum syariah semakin tinggi. Dari sepuluh bank umum syariah selama lima tahun terakhir, nilai rasio retained earnings to total assets yang tertinggi dimiliki oleh Bank Syariah Mandiri pada tahun 2013 dengan nilai 0.053. Arti nilai ini adalah setiap penggunaan Rp 1 aktiva oleh Bank Syariah Mandiri akan menghasilkan nilai laba ditahan sebesar Rp 0.053.

3. $\mathrm{X}_{3}=$ Earning Before Tax to Total Asset

Tabel 14 menunjukkan besarnya laba sebelum pajak yang dimiliki oleh bank umum syariah dari tahun 2010-2014:

Tabel 14. EBT (Laba Sebelum Pajak) -dalam jutaan rupiah

\begin{tabular}{rlrrrrr}
\hline & \multicolumn{1}{c}{ Bank } & \multicolumn{5}{c}{ Tahun } \\
No. & $\begin{array}{l}\text { Umum } \\
\text { Syariah }\end{array}$ & \multicolumn{1}{c}{$\mathbf{2 0 1 0}$} & \multicolumn{1}{c}{$\mathbf{2 0 1 1}$} & \multicolumn{1}{c}{$\mathbf{2 0 1 2}$} & \multicolumn{1}{c}{$\mathbf{2 0 1 3}$} & \multicolumn{1}{c}{$\mathbf{2 0 1 4}$} \\
\hline 1 & BMI & 231,076 & 371,670 & 521,841 & 653,621 & 96,719 \\
2 & BVS & 3,013 & 26,182 & 10,164 & 4,928 & $(25,021)$ \\
3 & BRIS & 18,053 & 16,701 & 138,052 & 183,942 & 29,615 \\
4 & BJBS & 7,696 & 25,769 & 20,843 & 18,759 & 29,751 \\
5 & BNIS & 36,734 & 89,356 & 137,744 & 179,616 & 220,133 \\
6 & BMS & 84,352 & 72,050 & 246,728 & 195,737 & 23,219 \\
7 & BPS & $(7,173)$ & 12,410 & 49,572 & 29,162 & 95,732 \\
8 & BSB & 14,919 & 15,023 & 24,354 & 27,245 & 12,770 \\
9 & BSM & 583,315 & 767,112 & $1,125,264$ & 906,498 & 112,608 \\
10 & BCAS & 6,285 & 8,950 & 10,961 & 16,761 & 17,498 \\
\hline
\end{tabular}

Sumber: data diolah

Data pada Tabel 14 earning before tax (laba sebelum pajak) yang telah dikemukakan di atas dapat dilihat pada tahun 2010 sampai tahun 2013 bank umum syariah yang memiliki laba sebelum pajak tertinggi dari bank lainnya adalah Bank Syariah Mandiri. Sedangkan di tahun 2014 laba sebelum pajak Bank Syariah Mandiri menurun cukup jauh dari tahun sebelumnya dan membuat BNI Syariah di tahun 2014 yang menjadi bank dengan laba sebelum pajak tertinggi. Data laba sebelum pajak tersebut kemudian dimasukkan ke dalam rumus dibawah ini: 
$\mathrm{X}_{3}=$ Earning Before Tax to Total Assets = Laba Sebelum Pajak

Total Aktiva

Penggunaan rumus tersebut dimaksudkan untuk menghasilkan nilai rasio earning before and tax (EBT) to total assets untuk bank umum syariah tahun 2010-2014. Maka Tabel 15 menunjukkan nilai rasio net working capital to total asset bank umum syariah tahun 2010-2014 yaitu:

Tabel 15. Hasil EBT (Laba Sebelum Pajak) to Total Assets

\begin{tabular}{rlrrrrr}
\hline No. & $\begin{array}{c}\text { Bank Umum } \\
\text { Syariah }\end{array}$ & $\mathbf{2 0 1 0}$ & \multicolumn{1}{c}{ 2011 } & \multicolumn{1}{c}{ 2012 } & \multicolumn{1}{c}{$\mathbf{2 0 1 3}$} & \multicolumn{1}{c}{$\mathbf{2 0 1 4}$} \\
\hline 1 & BMI & 0.011 & 0.011 & 0.012 & 0.012 & 0.0015 \\
2 & BVS & 0.009 & 0.0041 & 0.011 & 0.0037 & $(0.017)$ \\
3 & BRIS & 0.003 & 0.0015 & 0.0098 & 0.011 & 0.0015 \\
4 & BJBS & 0.004 & 0.009 & 0.005 & 0.004 & 0.005 \\
5 & BNIS & 0.006 & 0.011 & 0.013 & 0.012 & 0.11 \\
6 & BMS & 0.018 & 0.013 & 0.030 & 0.022 & 0.0033 \\
7 & BPS & $0.016)$ & 0.012 & 0.023 & 0.007 & 0.015 \\
8 & BSB & 0.006 & 0.006 & 0.007 & 0.006 & 0.002 \\
9 & BSM & 0.018 & 0.016 & 0.021 & 0.014 & 0.002 \\
10 & BCAS & 0.007 & 0.007 & 0.007 & 0.008 & 0.007 \\
\hline
\end{tabular}

Sumber: data diolah

Data pada Tabel 15 menunjukkan nilai rasio negatif dimiliki oleh Bank Panin Syariah pada tahun 2010 dan Bank Victoria Syariah untuk tahun 2014. Nilai negatif pada rasio ini disebabkan karena nilai laba sebelum pajak (EBT) dari kedua bank umum syariah tersebut juga bernilai negatif. Nilai negatif ini didapat karena jumlah beban yang harus dibayar oleh bank-bank tersebut lebih besar daripada jumlah pendapatan yang diterima. Selama lima tahun terakhir bank yang nilai laba sebelum pajaknya tertinggi adalah Bank Syariah Mandiri, namum rasio laba sebelum pajak terhadap total aktiva yang terbesar adalah BNI Syariah di tahun 2014 dengan nilai 0.11. Artinya, setiap penggunaan Rp 1 aktiva yang dimilki BNI Syariah akan menghasilkan nilai laba sebelum pajak sebesar Rp 0.11. Hal ini menunjukkan semakin tinggi nilai rasio laba sebelum pajak terhadap total aktiva maka menunjukkan semakin baiknya kinerja bank umum syariah dalam mengelola hartanya untuk menghasilkan laba sebelum pajak. 


\section{4. $\mathrm{X}_{4}=$ Book Value of Equity to Book Value of Total Debt}

Tabel 16 menunjukkan nilai buku ekuitas (Book Value of Equity) dari bank umum syariah, yaitu:

\section{Tabel 16. Nilai Buku Ekuitas (Book Value Of Equity) -dalam jutaan rupiah}

\begin{tabular}{rlrrrrr}
\hline \multirow{2}{*}{ No. } & Bank Umum & \multicolumn{5}{c}{ Tahun } \\
& \multicolumn{1}{c}{ Syariah } & $\mathbf{2 0 1 0}$ & $\mathbf{2 0 1 1}$ & $\mathbf{2 0 1 2}$ & $\mathbf{2 0 1 3}$ & \multicolumn{1}{c}{$\mathbf{2 0 1 4}$} \\
\hline 1 & BMI & 208,554 & 317,399 & 422,600 & 868,254 & $2,297,070$ \\
2 & BVS & 10,087 & 12,317 & 13,568 & 14,171 & 15,629 \\
3 & BRIS & 92,313 & 125,327 & 123,193 & 163,153 & 151,928 \\
4 & BJBS & 1,745 & 8,927 & 141,149 & 160,886 & 160,785 \\
5 & BNIS & 23,647 & 47,720 & 97,474 & 102,349 & 110,890 \\
6 & BMS & 68,718 & 61,983 & 57,403 & 51,082 & 288,933 \\
7 & BPS & 26,424 & 24,446 & 24,761 & 28,527 & 29,861 \\
8 & BSB & 43,994 & 57,646 & 58,393 & 85,176 & 80,808 \\
9 & BSM & 365,261 & 511,063 & 743,598 & 787,871 & 725,401 \\
10 & BCAS & 8,250 & 8,439 & 6,767 & 18,569 & 20,311 \\
\hline
\end{tabular}

Sumber: data diolah

Data pada Tabel 16 menunjukkan pada tahun 2010-2012 nilai buku ekuitas tertinggi ada pada Bank Syariah Mandiri dan untuk tahun 2013 dan 2014 nilai buku ekuitas tertinggi adalah Bank Muamalat Indonesia. Dapat dilihat juga bahwa nilai buku ekuitas, dari setiap bank umum syariah setiap tahunnya berfluktuasi kadang mengalami kenaikan dan kadang megalami penurunan.

Selanjutnya Tabel 17 adalah data yang menunjukkan Book Value of Debt yang dimiliki oleh bank umum syariah tahun 2010 sampai dengan tahun 2014. Data pada Tabel 17 menunjukkan bank umum syariah yang mempunyai total kewajiban tertinggi adalah Bank Syariah Mandiri pada tahun 2010-2014. Dapat dilihat pula bahwa nilai kewajiban bank umum syariah cenderung meningkat setiap tahunnya, penurunan nilai kewajiban pada bank umum syariah terjadi pada tahun 2014. Tahun 2014 ini, tujuh dari sepuluh bank umum syariah mempunyai nilai total kewajiban yang menurun dari tahun sebelumnya. Bankbank yang mengalami penurunan tersebut adalah Bank Victoria Syariah, Bank Jabar dan Banten Syariah, BNI Syariah, Bank Mega Syariah, Bank Panin Syariah, Bank Syariah Bukopin dan Bank Syariah Mandiri. 
Tabel 17. Nilai Buku Kewajiban (Book Value Of Debt) - jutaan rupiah

\begin{tabular}{rlrrrrr}
\hline No. & $\begin{array}{l}\text { Bank Umum } \\
\text { Syariah }\end{array}$ & \multicolumn{7}{c}{ Tahun } \\
& \multicolumn{2}{c}{$\mathbf{2 0 1 0}$} & $\mathbf{2 0 1 1}$ & $\mathbf{2 0 1 2}$ & $\mathbf{2 0 1 3}$ & \multicolumn{1}{c}{$\mathbf{2 0 1 4}$} \\
\hline 1 & BMI & 208,554 & 317,399 & 422,600 & 868,254 & $2,297,070$ \\
2 & BVS & 35,773 & 64,653 & 161,748 & 119,634 & 84,238 \\
3 & BRIS & $1,192,418$ & $2,230,290$ & $3,431,739$ & $4,504,515$ & $5,611,539$ \\
4 & BJBS & 274,658 & 350,268 & 575,579 & 711,187 & 583,989 \\
5 & BNIS & 825,370 & $1,746,689$ & $2,366,763$ & $4,272,233$ & $3,859,672$ \\
6 & BMS & $1,397,796$ & $1,820,331$ & $2,118,304$ & $1,905,341$ & $1,345,853$ \\
7 & BPS & 20,802 & 163,564 & 612,730 & $1,026,305$ & 892,549 \\
8 & BSB & 698,558 & 492,386 & 905,598 & $1,564,054$ & $1,136,981$ \\
9 & BSM & $5,009,834$ & $7,741,140$ & $9,168,631$ & $11,029,685$ & $9,609,312$ \\
10 & BCAS & 111,270 & 190,216 & 268,793 & 275,000 & 326,917 \\
\hline
\end{tabular}

Sumber: data diolah

Data dari nilai buku kewajiban tersebut kemudian dimasukkan ke dalam rumus:

$$
\mathrm{X}_{4}=\text { Book Value of Equity to Book Value of Debt }=\frac{\text { Nilai Buku Ekuitas }}{\text { Total Kewajiban }}
$$

Penggunaan rumus tersebut dimaksudkan untuk menghasilkan nilai rasio book value of equity to book value of debt untuk bank umum syariah tahun 2010-2014. Tabel di bawah ini menunjukkan nilai rasio bookvalue of equity to book value of debt bank umum syariah tahun 2010-2014 yaitu:

\begin{tabular}{|c|c|c|c|c|c|c|}
\hline \multirow{2}{*}{ No. } & \multirow{2}{*}{$\begin{array}{c}\text { Bank Umum } \\
\text { Syariah }\end{array}$} & \multicolumn{5}{|c|}{ Tahun } \\
\hline & & 2010 & 2011 & 2012 & 2013 & 2014 \\
\hline 1 & BMI & 0.057 & 0.069 & 0.052 & 0.088 & 0.21 \\
\hline 2 & BVS & 0.28 & 0.19 & 0.084 & 0.12 & 0.18 \\
\hline 3 & BRIS & 0.078 & 0.056 & 0.036 & 0.036 & 0.027 \\
\hline 4 & BJBS & 0.006 & 0.025 & 0.245 & 0.226 & 0.275 \\
\hline 5 & BNIS & 0.029 & 0.027 & 0.041 & 0.024 & 0.029 \\
\hline 6 & BMS & 0.049 & 0.034 & 0.027 & 0.027 & 0.215 \\
\hline 7 & BPS & 1.27 & 0.15 & 0.040 & 0.028 & 0.033 \\
\hline 8 & BSB & 0.063 & 0.12 & 0.064 & 0.054 & 0.071 \\
\hline 9 & BSM & 0.073 & 0.066 & 0.081 & 0.071 & 0.075 \\
\hline 10 & BCAS & 0.074 & 0.044 & 0.025 & 0.068 & 0.062 \\
\hline
\end{tabular}

Tabel 18. Hasil Book Value of Equity to Book Value of Debt $\left(\mathrm{X}_{4}\right)$

Sumber: data diolah

Data pada Tabel 18 menunjukkan bahwa data dari rasio perbandingan antara nilai buku ekuitas terhadap total kewajiban tertinggi pada tahun 2010 
dimiliki oleh Bank Panin Syariah, tahun 2011 berpindah ke Bank Victoria Syariah dan untuk tahun 2012-2014 dimiliki oleh Bank Jabar dan Banten Syariah. Semakin tinggi nilai rasio ini maka menunjukkan bank umum syariah mampu memenuhi seluruh kewajibannya dengan nilai buku ekuitas yang dimiliki oleh bank-bank tersebut.

Rasio tertinggi dalam waktu lima tahun terakhir dimiliki oleh Bank Panin Syariah pada tahun 2010 dengan nilai 1.27, artinya adalah setiap Rp 1 total kewajiban yang dimiliki Bank Panin Syariah dicakup sebesar Rp 1.27 oleh nilai buku ekuitas yang dimiliki bank tersebut.

\section{Hasil Altman Z-Score Modifikasi}

Berdasarkan data dari perhitungan keempat variabel yang digunakan dalam model Altman Z-score modifikasi di atas, maka langkah selanjutnya adalah memasukkan hasil tersebut kedalam model persamaan dari Altman Zscore modifikasi dengan mengkalikan hasil data di atas dengan nilai konstanta atau standar dari masing-masing variabel. Model Persamaan dan hasil dari perhitungan berdasarkan Z-score modifikasi adalah:

$$
Z=6,56 \times 1+3,26 \times 2+6,72 \times 3+1,05 \times 4
$$

Hasil Analisis Model Altman Z-Score Modifikasi Tahun 2010, setelah dimasukkan ke dalam persamaan di atas adalah:

Tabel 19. Perhitungan Z-Score BUS Tahun 2010

\begin{tabular}{rlrrrrr}
\hline No. & $\begin{array}{c}\text { Bank Umum } \\
\text { Syariah }\end{array}$ & $\mathbf{6 . 5 6}\left(\mathbf{X}_{\mathbf{1}}\right)$ & $\mathbf{3 . 2 6}\left(\mathbf{X}_{\mathbf{2}}\right)$ & $\mathbf{6 . 7 2}\left(\mathbf{X}_{\mathbf{3}}\right)$ & $\mathbf{1 . 0 5}\left(\mathbf{X}_{\mathbf{4}}\right)$ & Z-Score \\
\hline 1 & BMI & 5.31 & 0.068 & 0.074 & 0.06 & 5.51 \\
2 & BVS & 5.44 & 0 & 0.06 & 0.29 & 5.75 \\
3 & BRIS & 5.38 & $(0.0114)$ & 0.02 & 0.082 & 5.47 \\
4 & BJBS & 5.71 & 0.009 & 0.027 & 0.006 & 5.76 \\
5 & BNIS & 5.71 & 0.02 & 0.04 & 0.03 & 5.80 \\
6 & BMS & 4.46 & 0.046 & 0.121 & 0.05 & 4.68 \\
7 & BPS & 5.84 & $0.059)$ & $0.11)$ & 1.34 & 6.98 \\
8 & BSB & 4.33 & $(0.31)$ & 0.04 & 0.07 & 4.13 \\
9 & BSM & 5.25 & 0.137 & 0.121 & 0.077 & 5.59 \\
10 & BCAS & 5.71 & 0.013 & 0.047 & 0.078 & 5.85 \\
\hline
\end{tabular}

Sumber: data diolah

Berdasarkan hasil perhitungan di atas, nilai z-score dari keseluruhan bank umum syariah pada tahun 2010 melebihi nilai 2.9. Artinya seluruh bank umum syariah dikategorikan dalam keadaan tidak bangkrut. Pada tahun ini nilai 
z-score tertinggi adalah Bank Panin Syariah dan nilai z-score terendah adalah Bank Syariah Bukopin. Selanjutnya dengan menggunakan rumus persamaan yang sama, maka hasil perhitungan z-score pada tahun 2011 adalah:

Tabel 20. Perhitungan Z-Score BUS tahun 2011

\begin{tabular}{rlrrrrr}
\hline No. & $\begin{array}{c}\text { Bank Umum } \\
\text { Syariah }\end{array}$ & $\mathbf{6 . 5 6}\left(\mathbf{X}_{\mathbf{1}}\right)$ & $\mathbf{3 . 2 6}\left(\mathbf{X}_{\mathbf{2}}\right)$ & $\mathbf{6 . 7 2}\left(\mathbf{X}_{\mathbf{3}}\right)$ & $\mathbf{1 . 0 5}\left(\mathbf{X}_{\mathbf{4}}\right)$ & \multicolumn{1}{c}{ Z-Score } \\
\hline 1 & BMI & 5.51 & 0.068 & 0.074 & 0.072 & 5.72 \\
2 & BVS & 5.77 & 0.134 & 0.027 & 0.285 & 6.25 \\
3 & BRIS & 5.19 & $(0.0036)$ & 0.01008 & 0.059 & 5.26 \\
4 & BJBS & 5.84 & 0.023 & 0.06 & 0.026 & 5.95 \\
5 & BNIS & 5.24 & 0.03 & 0.07 & 0.028 & 5.37 \\
6 & BMS & 4.4 & 0.068 & 0.087 & 0.036 & 4.59 \\
7 & BPS & 5.31 & 0.0011 & 0.081 & 0.16 & 5.55 \\
8 & BSM & 5.12 & $0.23)$ & 1.12 & 0.13 & 6.14 \\
9 & BSB & 5.51 & 0.127 & 0.108 & 0.069 & 5.81 \\
10 & BCAS & 5.51 & 0.03 & 0.047 & 0.046 & 5.63 \\
\hline
\end{tabular}

Sumber: data diolah

Hasil perhitungan untuk tahun 2011 menunjukkan sepuluh bank umum syariah tersebut masih dalam kategori tidak bangkrut, untuk tahun ini nilai zscore tertinggi ada pada Bank Victoria Syariah dan nilai z-score terendah yaitu Bank Syariah Mega. Perhitungan z-score untuk tahun 2012, dengan persamaan yang sama seperti di atas didapatkan hasil sebagai berikut:

Tabel 21. Perhitungan Z-Score BUS Tahun 2012

\begin{tabular}{rlrrrrr}
\hline No. & $\begin{array}{c}\text { Bank } \\
\text { Umum } \\
\text { Syariah }\end{array}$ & $\mathbf{6 . 5 6}\left(\mathbf{X}_{\mathbf{1}}\right)$ & $\mathbf{3 . 2 6}\left(\mathbf{X}_{\mathbf{2}}\right)$ & $\mathbf{6 . 7 2}\left(\mathbf{X}_{\mathbf{3}}\right)$ & $\mathbf{1 . 0 5}\left(\mathbf{X}_{\mathbf{4}}\right)$ & Z-Score \\
\hline 1 & BMI & 5.25 & 0.12 & 0.081 & 0.055 & 5.51 \\
2 & BVS & 5.24 & 0.025 & 0.074 & 0.088 & 5.48 \\
3 & BRIS & 4.99 & $0.00028)$ & 0.066 & 0.038 & 5.09 \\
4 & BJBS & 5.51 & 0.016 & 0.037 & 0.26 & 5.82 \\
5 & BNIS & 5.12 & 0.055 & 0.087 & 0.043 & 5.30 \\
6 & BMS & 4.85 & 0.121 & 0.202 & 0.028 & 5.20 \\
7 & BPS & 4.07 & 0.059 & 0.15 & 0.042 & 4.32 \\
8 & BSM & 4.72 & $0.16)$ & 0.05 & 0.01 & 4.62 \\
9 & BSM & 5.38 & 0.166 & 0.141 & 0.085 & 5.77 \\
10 & BCAS & 5.44 & 0.04 & 0.047 & 0.026 & 5.55 \\
\hline
\end{tabular}

Sumber: data diolah

Tabel 21 menunjukkan seluruh bank umum syariah tetap berada pada kategori tidak bangkrut, hasil ini sama seperti tahun-tahun sebelumnya. Pada tahun ini Bank yang memliki nilai z-score tertinggi dibandingkan bank yang lain adalah Bank Jabar dan Banten Syariah dengan nilai 5.82 dan bank yang memiliki nilai z-score terendah adalah Bank Panin Syariah dengan nilai 
4.32. Hasil dari analisis tahun 2013 berdasarkan model Altam Z-score pada Tabel 22.

Tabel 22. Perhitungan Z-Score BUS Tahun 2013

\begin{tabular}{rlrrrrr}
\hline No. & $\begin{array}{c}\text { Bank Umum } \\
\text { Syariah }\end{array}$ & $\mathbf{6 . 5 6}\left(\mathbf{X}_{\mathbf{1}}\right)$ & $\mathbf{3 . 2 6}\left(\mathbf{X}_{\mathbf{2}}\right)$ & $\mathbf{6 . 7 2}\left(\mathbf{X}_{\mathbf{3}}\right)$ & $\mathbf{1 . 0 5}\left(\mathbf{X}_{\mathbf{4}}\right)$ & Z-Score \\
\hline 1 & BMI & 5.18 & 0.065 & 0.081 & 0.092 & 5.42 \\
2 & BVS & 5.9 & 0.081 & 0.025 & 0.126 & 6.13 \\
3 & BRIS & 4.85 & 0.0167 & 0.074 & 0.038 & 4.98 \\
4 & BJBS & 5.34 & 0.03 & 0.027 & 0.24 & 5,64 \\
5 & BNIS & 4.72 & 0.068 & 0.08 & 0.025 & 4.89 \\
6 & BMS & 4.92 & 0.052 & 0.147 & 0.028 & 5.15 \\
7 & BPS & 4.85 & 0.02 & 0.047 & 0.029 & 4.95 \\
8 & BSB & 4.59 & -0.12 & 0.04 & 0.06 & 4.57 \\
9 & BSM & 5.18 & 0.173 & 0.094 & 0.075 & 5.52 \\
10 & BCAS & 5.64 & 0.052 & 0.054 & 0.071 & 5.82 \\
\hline
\end{tabular}

Sumber: data diolah

Hasil perhitungan nilai z-score tahun 2013 di atas menunjukkan nilai zscore tertinggi ada pada Bank Victoria Syariah dengan nilai 6.13 dan nilai zscore terendah ada pada Bank Syariah Bukopin dengan nilai 4.57. Berdasarkan data pada tabel di atas juga menunjukkan seluruh bank umum syariah masih berada pada kategori tidak bangkrut. Hasil dari analisis tahun 2014 berdasarkan model Altam Z-score modifikasi seperti di atas, maka diperoleh hasilnya sebagai berikut:

Tabel 23. Perhitungan Z-Score BUS Tahun 2014

\begin{tabular}{rlrrrrr}
\hline No. & $\begin{array}{c}\text { Bank Umum } \\
\text { Syariah }\end{array}$ & $\mathbf{6 . 5 6}\left(\mathbf{X}_{\mathbf{1}}\right)$ & $\mathbf{3 . 2 6}\left(\mathbf{X}_{\mathbf{2}}\right)$ & $\mathbf{6 . 7 2}\left(\mathbf{X}_{\mathbf{3}}\right)$ & $\mathbf{1 . 0 5}\left(\mathbf{X}_{\mathbf{4}}\right)$ & \multicolumn{1}{l}{ Z-Score } \\
\hline 1 & BMI & 5.18 & 0.036 & 0.0101 & 0.22 & 5.45 \\
2 & BVS & 6.03 & 0.085 & $0.114)$ & 0.189 & 6.19 \\
3 & BRIS & 5.18 & 0.036 & 0.01008 & 0.028 & 5.25 \\
4 & BJBS & 0.88 & 0.006 & 0.005 & 0.275 & 6.11 \\
5 & BNIS & 5.31 & 0.075 & 0.074 & 0.03 & 5.49 \\
6 & BMS & 5.12 & 0.00815 & 0.022176 & 0.23 & 5.38 \\
7 & BPS & 5.58 & 0.052 & 0.1008 & 0.035 & 5.77 \\
8 & BSB & 4.99 & $0.09)$ & 0.013 & 0.07 & 4.98 \\
9 & BSM & 5.51 & 0.166 & 0.013 & 0.079 & 5.77 \\
10 & BCAS & 5.84 & 0.055 & 0.047 & 0.065 & 6.01 \\
\hline
\end{tabular}

Sumber: data diolah

Data pada Tabel 23 ini menunjukkan bahwa seluruh bank umum syariah memiliki hasil yang sama dengan empat tahun sebelumnya yaitu seluruh bank umum syariah berada pada kategori tidak bangkrut. Hasil ini diperoleh berdasarkan nilai z-score yang dimiliki oleh seluruh bank umum syariah pada tahun 2014 ini masih lebih besar dari 2.90. Nilai z-score tertinggi 
untuk tahun 2014 ini dimiliki oleh Bank Victoria Syariah yaitu sebesar 6.19 dan nilai z-score terendah dimiliki oleh Bank Syariah Bukopin yaitu sebesar 4.98 .

Berdasarkan hasil dari proses yang peritungan nilai z-score menggunakan model Altman Z-score modifikasi di atas dapat diketahui seluruh bank umum syariah dalam rentang waktu lima tahun terakhir berada pada kategori tidak bangkrut. Nilai rata-rata z-score untuk seluruh BUS tahun 20102014 ditunjukkan pada grafik di bawah ini:

Gambar 1. Rata-Rata Nilai Z-Score BUS Tahun 2010-2014

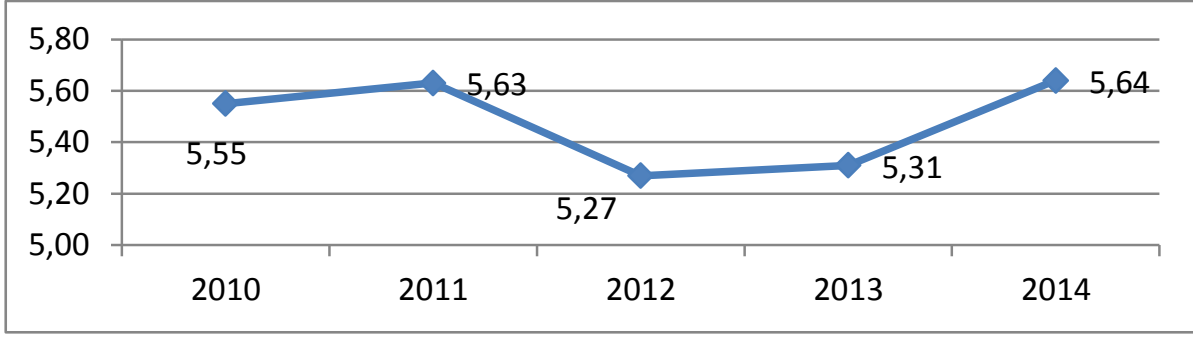

Sumber: data diolah

Gambar 1 menunjukkan bahwa tren nilai z-score bank umum syariah selama tahun 2010-2014 menunjukkan pergerakan yang cenderung stabil. Penurunan nilai z-score yang terjadi pada tahun 2012 jika diteliti disebabkan karena menurunnya nilai rasio net working capital to total assets dan rasio book value of equity to book value of debt. Hal ini dapat dibuktikan dengan Tabel 24.

Tabel 24. Rata-Rata Nilai Variabel Altman Z-Score Modifikasi

\begin{tabular}{rrrrrr}
\hline Tahun & \multicolumn{1}{c}{ WCTA } & \multicolumn{1}{c}{ RETA } & EBITTA & \multicolumn{1}{c}{ BVEBVD } & \multicolumn{1}{c}{ Z-Score } \\
\hline 2010 & 5.31 & 0.019 & 0.044 & 0.208 & 5.55 \\
2011 & 5.34 & 0.023 & 0.168 & 0.091 & 6.63 \\
2012 & 5.06 & 0.442 & 0.093 & 0.067 & 5.23 \\
2013 & 5.12 & 0.044 & 0.067 & 0.078 & 5.31 \\
2014 & 5.45 & 0.043 & 0.018 & 0.122 & 5.64
\end{tabular}

Sumber: data diolah

Jika dilihat pada tahun 2012 ada penurunan nilai net working capital to total assets (WCTA) dan book value of equity to book value of debt (BVEBVD) yang menyebabkan turunnya nilai z-score. Nilai yang turun di tahun 2012 memang tidak hanya kedua variabel tersebut, tapi juga nilai dari earning before interest and tax to total assets (EBITTA). Namun hal ini tidak mempengaruhi 
nilai z-score, karena bila dilihat pada tahun 2013 dan 2014 nilai rasio EBITTA juga menurun tapi nilai z-scorenya justru naik. Kenaikan nilai z-score pada tahun 2013 dan 2014 ini disebabkan karena nilai dari variabel WCTA dan BVEBVD mengalami peningkatan dari tahun sebelumnya. Jadi dapat ditarik kesimpulan bahwa net working capital to total assets dan book value of equity to book value of debt mempunyai pengaruh lebih besar dalam menentukan nilai zscore dibandingkan dengan variabel lainnya. Hasil menunjukkan bahwa nilai zscore tertinggi bank umum syariah setiap tahunnya digambarkan pada Gambar.2.

Gambar 2. Nilai Z-Score Tertinggi Tahun 2010-2014

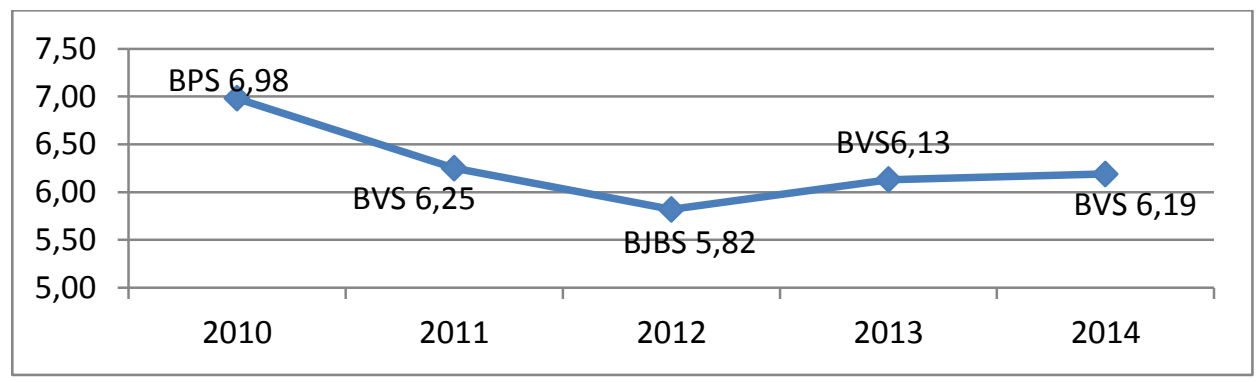

Sumber: data diolah

Berdasarkan grafik hasil perhitungan z-score bank umum syariah yang memiliki nilai z-score tertinggi paling banyak selama lima tahun terakhir adalah Bank Victoria Syariah yaitu pada tahun 2011, 2013 dan 2014. Sedangkan Bank Panin Syariah dan Bank Jabar dan Banten Syariah masing-masing hanya sekali mendapatkan nilai z-score tertinggi yaitu tahun 2010 dan 2011. Jika diamati bank umum syariah yang memiliki nilai z-score tertinggi pada setiap tahunnya adalah bank syariah yang berdiri kurang dari lima tahun, dikarenakan bankbank umum syariah baru ini memiliki nilai kewajiban atau hutang yang masih relatif kecil dibandingkan dengan bank syariah yang telah lama berdiri. Selain itu jumlah aktiva yang dimiliki oleh bank-bank tersebut lebih mampu dioptimalkan ke dalam bentuk modal kerja, meski laba yang dihasilkan masih rendah.

Hasil penelitian menunjukkan bahwa kondisi keuangan bank umum syariah menunjukkan hasil yang stabil cenderung meningkat. Hasil ini di dapat karena kegiatan usaha yang dilakukan baik dalam kegiatan penghimpunan dan 
penyaluran dana oleh bank syariah cenderung dengan aman. Maksud aman disini adalah bank syariah dalam melakukan transaksi berlandaskan pada asset dasar (underlying assets) dan kegiatan penyaluran dana bank syariah lebih ke arah sektor riil dalam perekonomian domestik. Berbeda dengan bank konvensional yang kegiatan usahanya cenderung lebih kearah spekulatif dengan melakukan transaksi-transaksi keuangan yang mempunyai risiko tinggi. Spekulatif disini maksudnya adalah dengan tergantung pada tingkat suku bunga, karena keuntungan terbesar bank konvensional didapatkan dari selisih antara besarnya bunga yang dikenakan kepada para peminjam dana dengan imbalan bunga yang diberikan kepada nasabah penyimpan.

Penelitian ini juga menunjukkan bahwa kesehatan bank umum syariah tidak terganggu meskipun krisis ekonomi sedang melanda Indonesia, hal ini dibuktikan dengan bank umum syariah yang berdasarkan pengukuran tingkat kesehatan berada kategori sehat. Selain itu dilihat dari prediksi potensi kebangkrutan yang dilakukan bank umum syariah berada pada kategori tidak bangkrut. Hal ini menunjukkan bahwa bank syariah dapat bertahan dalam industri perbankan nasional dan selamat dari krisis keuangan global yang menyebabkan besarnya potensi kebangkrutan pada bank. Alasannya karena industri perbankan syariah lebih fleksibel dalam kondisi dan situasi apapun. Ketahanan bank syariah dalam menghadapi krisis yang mengancam kelangsungan usaha bank tersebut dikarenakan prinsip dasar dari bank syariah yang mengedepankan konsep bagi hasil pada kegiatan penghimpunan maupun penyaluran dana, sehingga risiko ditanggung bersama antara bank dengan pihak nasabah.

Contohnya kegiatan ini seperti pada saat rasio pembiayaan bermasalah (NPF) bank syariah meningkat yang menyebabkan penurunan laba yang dihasilkan oleh bank syariah, dalam keadaan ini bagi hasil yang didapat oleh nasabah yang menyimpan dananya pada bank syariah juga terkena imbas dengan menurunnya bagi hasil yang didapat oleh nasabah tersebut. Oleh karena itulah bank syariah lebih tahan krisis karena risiko yang dialami oleh bank syariah tidak ditanggung sendiri. Berbeda dengan bank konvensional yang berbasis bunga, dimana bank konvensional harus membayar kewajiban 
sesuai dengan bunga yang ditetapkan meski pendapatan yang diterima lebih rendah.

Hasil penelitian juga menunjukkan bahwa bank syariah adalah bank yang aman, sehat dan dapat dipercaya oleh masyarakat untuk menyimpan uang atau menginvestasikan dana yang dimiliki. Hal ini dapat dilihat dari rasio CAR dan NCOM yang dimiliki oleh bank syariah. Nilai rasio CAR yang lebih dari $8 \%$ menunjukkan bank syariah mempunyai kekuatan modal yang cukup kuat untuk membantu membiayai kegiatan usahanya dan mampu mengcover kesulitan yang mungkin terjadi pada bank umum syariah tersebut. Sedangkan untuk nilai rasio NCOM yang lebih dari 3\% menunjukkan bank umum syariah mampu menghasilkan pendapatan yang tinggi dari kegiatan penyaluran dana yang bank syariah lakukan.

Bank syariah yang mempunyai nilai laba tinggi berpotensi untuk mempunyai tingkat bagi hasil yang besar pula kepada para nasabahnya. Bank syariah yang kondisi labanya cenderung stabil dan meningkat setiap tahunnya adalah Bank Muamalat Indonesia, Bank Syariah Mandiri, Bank Syariah Mega dan BRI Syariah. Bank umum syariah yang mempunyai modal yang kuat berpotensi akan terjaga tingkat likuiditasnya. Masyarakat dapat memilih bank syariah yang mempunyai modal (CAR) yang kuat seperti BNI Syariah, Bank Panin Syariah, BRI Syariah, Bank Jabar dan Banten Syariah, atau BCA Syariah.

Hasil penelitian ini mempunyai hasil penelitian yang sejalan dengan hasil penelitian yang dilakukan terdahulu dalam mengukur tingkat kesehatan bank umum syariah. Penelitian yang sejalan adalah penelitian yang dilakukan oleh:

1. Sri Fatimah Rahmatillah (2014) dengan menggunakan metode RGEC memperoleh hasil bahwa Bank Syariah Bukopin, BNI Syariah, BRI Syariah, Bank Syariah Mandiri, BCA Syariah, Bank Panin Syariah, Bank Syariah Mega, Bank Victoria Syariah dan Bank Muamalat Indonesia tahun 2011-2013 dinyatakan dalam tingkat kesehatan yang sehat. 
2. Mahmudah (2013), penelitian tingkat kesehatan terhadap Bank Syariah Mandiri, Bank Muamalat Indonesia dan BRI Syariah pada tahun 2010-2012 menggunakan metode RGEC menunjukkan bahwa bank umum syariah berada pada tingkat kesehatan yang sehat.

Hasil penelitian yang sejalan dengan penulis dalam memprediksi potensi kebangkrutan bank umum syariah adalah

1. Penelitian yang dilakukan oleh Bella Myirandasari (2015) yang mengatakan BNI Syariah, Bank Mega Syariah, Bank Syariah Mandiri dan Bank Muamalat Indonesia tahun 2011-2013 berada pada kategori tidak bangkrut. Hal ini karena nilai rata-rata z-score bank umum syariah selama 3 tahun menunjukkan nilai 5.29. Artinya nilai ini lebih besar dari 2.90, hasil ini diperoleh dengan menggunakan model analisis Altman z-score modifikasi. Sedangkan hasil penelitian ini menunjukkan bahwa nilai rata-rata z-score untuk keempat bank umum syariah di atas tahun 2011-2013 menunjukkan hasil 5.28. Perbedaan nilai ini dikarenakan ada perbedaan pembulatan dalam nilai.

2. Sri Fatimah Rahmatillah (2014) yang mengatakan bahwa Bank Syariah Bukopin, BNI Syariah, BRI Syariah, Bank Syariah Mandiri, BCA Syariah, Bank Panin Syariah, Bank Mega Syariah, Bank Victoria Syariah dan Bank Muamalat Indonesia tahun 2011-2013 dinyatakan dalam kategori tidak bangkrut. Hasil rata-rata nilai z-score yang diperoleh sebesar 5.40. Hasil didapat dengan menggunakan model analisis Altman z-score modifikasi. Hasil penelitian penulis juga menunjukkan nilai rata-rata yang sama dengan hasil penelitian Sri Fatimah.

Hasil yang berbeda dengan penelitian sebelumnya terjadi dengan penelitian yang dilakukan oleh Muhamad Nadratuzzaman dan Shofaun Nada (2013) yang menyatakan bahwa Bank Muamalat Indonesia, Bank Syariah Mandiri dan Bank Mega Syariah pada tahun 2010 berada pada kategori bangkrut. Hasil ini didapat karena nilai z-score bank umum syariah tersebut dibawah 1.81. Perbedaan terjadi karena bila dalam peneltian ini penulis menggunakan model analisis Altman z-score modifikasi, sedangkan penelitian yang dilakukan oleh Muhamad Nadratuzzaman dan Shofaun Nada 
menggunakan model analisis Altman z-score revisi. Perbedaan kedua model ini terletak pada variabel yang digunakan, dalam model Altman z-score revisi ada variabel sales to total assets sedangkan dalam model Altman z-score modifikasi tidak ada. Selain perbedaan variabel, perbedaan lain ada pada nilai konstanta yang harus dikalikan dengan masing-masing nilai dari variabel juga berbeda dan juga perbedaan pada batas nilai z-score yang harus dipenuhi. Penjelasan lebih jelas sudah diterangkan pada bab 2 dalam penelitian ini.

Dari penjabaran di atas maka dapat ditarik kesimpulan bahwa Altman z-score memang dapat digunakan sebagai sistem pencegahan dini untuk memprediksi potensi kebangkrutan pada perusahaan. Tapi karena model analisis Altman Z-Score ini mempunyai beberapa bentuk, maka dalam memilih model analisis ini juga harus diperhatikan. Model Altman yang digunakan harus sesuai dengan bentuk perusahaan yang akan dijadikan objek penelitian.

Penelitian ini menggunakan kondisi keuangan bank umum syariah sebagai objek penelitian, maka model analisis Altman z-score yang digunakan harus sesuai dengan karakteristik yang dimiliki oleh bank yang merupakan perusahaan jasa keuangan. Berdasarkan teori, model analisis yang dinilai lebih baik digunakan untuk memprediksi potensi kebangkrutan bank syariah menggunakan model Altman z-score adalah bentuk model Altman z-score modifikasi.

Alasan pemilihan model Altman z-score modifikasi ini karena bank syariah berbeda dengan perusahaan manufaktur jadi bank syariah tidak cocok menggunakan model Altman z-score original ataupun Altman z-score revisi, hal ini karena kedua model Altman tersebut adalah model yang dibuat untuk memprediksi kebangkrutan dari perusahaan maufaktur baik yang sudah go public maupun yang belum. Sedangkan Altman z-score modifikasi adalah sebual model analisis alternatif yang dikembangkan oleh Altman agar dapat digunakan pada perusahaan non manufaktur, dalam model ini variable $\mathrm{X}_{5}$ dihilangkan. Ini karena dalam perusahaan non manufaktur tidak ada akun sales (penjualan). 
Dari interpretasi penelitian yang telah dijabarkan dapat ditarik kesimpulan bahwa sebenarnya bank umum syariah adalah bank yang memiliki kinerja yang baik dan bank yang kredibel sebagai lembaga keuangan yang menghimpun dan menyalurkan dana masyarakat. Meski eksistensi bank umum syariah belum lama seperti bank konvensional dan laba yang dihasilkan juga belum setara dengan bank konvensional, tapi bank umum syariah sudah terbukti dapat bertahan dari guncangan krisis ekonomi yang terjadi di Indonesia pada tahun 1997 dan 2008. Bila dilihat pada tahun-tahun krisis tersebut di mana banyak bank konvensional tutup karena kesulitan keuangan, keadaan berbeda ditunjukkan oleh bank umum syariah di mana pada saat itu tidak ada bank umum syariah yang dilikuidasi oleh pemerintah atau diakuisisi oleh bank lain karena masalah kesulitan keuangan akibat krisis yang melanda.

Meskipun demikian bank umum syariah harus tetap menerapkan prinsip kehati-hatian dengan lebih baik lagi, kelangsungan usaha bank umum syariah di masa depan bukan hanya dilihat dari nilai rasio-rasio keuangan yang menunjukkan hasil yang baik tetapi juga dilihat dari tata kelola manajemen yang baik. Hal ini dikarenakan bila ada bank umum syariah yang kolaps akibat manajemen yang salah urus akan membuat pandangan masyarakat menjadi rusak, kepercayaan terhadap bank syariah menjadi menurun dan membuat pandangan di masyarakat bahwa bank syariah tidak terjamin keamanannya. Sebenarnya banyak bank yang kolaps bukan karena kondisi keuangannya yang buruk atau pendapatan bank yang menurun, tetapi karena kesalahan yang dibuat oleh manajemen bank sehingga menyebabkan kesulitan likuiditas pada bank tersebut. Likuiditas bank yang menurun akan langsung membuat bank tersebut kehilangan kepercayaan dari masyarakat dan menyebabkan masyarakat ingin menarik uangnya dari bank tersebut. Jadi dalam konteks menjaga kestabilan keuangan perbankan syariah dan terus menjaga kelangsungan usaha bank umum syariah yang harus diperhatikan adalah kinerja keuangannya, tingkat likuiditasnya dan tata kelola manajemen bank tersebut. 


\section{SIMPULAN}

Hasil penelitian menunjukkan bahwa kondisi keuangan bank umum syariah menunjukkan hasil yang stabil cenderung meningkat. Penelitian ini juga menunjukkan bahwa kesehatan bank umum syariah tidak terganggu meskipun krisis ekonomi sedang melanda Indonesia. Hasil penelitian juga menunjukkan bahwa bank syariah adalah bank yang aman, sehat dan dapat dipercaya oleh masyarakat untuk menyimpan uang atau menginvestasikan dana yang dimiliki. Altman z-score memang dapat digunakan sebagai sistem pencegahan dini untuk memprediksi potensi kebangkrutan pada perusahaan. Alasan pemilihan model Altman z-score modifikasi ini karena bank syariah berbeda dengan perusahaan manufaktur jadi bank syariah tidak cocok menggunakan model Altman z-score original ataupun Altman z-score revisi.

\section{PUSTAKA ACUAN}

Altman, E.I. 1968. Financial Ratios, Discriminant Analysis And The Prediction of Corporate Bankruptcy. The Journal of Finance. Vol. 23 No. 4, pp. 51-64.

Alkatiri, L.A. 2007. Analisis Risiko Kebangkrutan Z-Score Altman Pada Bank Syariah dan Bank Non Syariah. (Skripsi Tidak Dipublikasikan). Yogyakarta: Universitas Negeri Yogyakarta.

Adnan, M. A. \& I. Taufiq. 2001. Analisis Ketepatan Prediksi Metode Altman Terhadap Terjadinya Likuidasi Pada Lembaga Perbankan (Kasus Likuidasi Perbankan Di Indonesia). Jurnal Akuntansi. Vol 5 No 2.

Anggaraini, Y. R. 2011. Analisis Prediksi Kebangkrutan Perbankan Berdasarkan Model Altman Z-Score pada PT. Bank Rakyat Indonesia (Persero), Tbk. (Skripsi Tidak Dipublikasikan). Jember: Universitas Jember.

Arifin, Z. 1999. Memahami Bank Syariah Lingkup, Peluang, Tantangan, dan Prospek. Jakarta: AlvaBet.

Boediono \& W. Koster. 2008. Teori dan Aplikasi Statistika dan Probabilitas. Bandung: PT. Remaja Rosdakarya. 
Endri. 2008. Prediksi Kebangkrutan Bank Untuk Menghadapi dan Mengelola Perubahan Lingkungan Bisnis: Analisis Model Altman Z-Score. Perbanas Quarterly Review. Vol.2..

Harahap, S.S. 2004. dkk. Akuntansi Perbankan Syariah: Edisi Revisi. Jakarta: Lembaga Penerbit Fakultas Ekonomi Universitas Trisakti (LPFE Usakti).

Harahap, S.S. 2009. Analisis Kritis Atas Laporan Keuangan. Jakarta: PT. Raja Grafindo Persada.

Ikatan Akuntansi Indonesia. 2007. PSAK No 101 Standar Akuntansi Keuangan. Jakarta: Ikatan Akuntansi Indonesia.

Kasmir. 2014. Analisis Laporan Keuangan. Jakarta: PT. Raja Grafindo Persada. Myirandasari, B. 2015. Analisis Komparasi Stabilitas Perbankan Syariah dan Konvensional (Bank Umum Devisa Non Go Public di Indonesia). Jurnal Ilmiah. Universitas Brawijaya Malang.

Hosen, M. N \& S. Nada. 2012. Pengukuran Tingkat Kesehatan dan Gejala Financial Distress Bank Umum Syariah. Jurnal Economia, Vol. 9 No. 2.

Nurhasanah. 2010. Analisis Rasio Keuangan Model Altman dan Model Springate Sebagai Early Warning System Terhadap Prediksi Kondisi Bermasalah Pada Bank Go Public. (Skripsi Tidak Dipublikasikan). Jakarta: Universitas Islam Negeri Syarif Hidayatullah Jakarta.

Nurhayati, S. \& Wasilah. 2009. Akuntansi Syariah di Indonesia. Jakarta: Salemba Empat.

Peraturan Bank Indonesia No. 13/1/PBI/2011 Tentang Penilaian Tingkat Kesehatan Bank Umum.

Peraturan Bank Indonesia No. 8/4/PBI/2006. "Tentang Pelaksanaan GCG Bagi Bank Umum".

Peraturan Bank Indonesia No.15/12/PBI/2013. "Tentang Kewajiban Penyediaan Modal Minimum".

Peraturan Otoritas Jasa Keuangan Nomor 8/POJK.03/2014 Tentang Penilaian Tingkat Kesehatan Bank Umum Syariah Dan Unit Usaha Syariah. 
Ramadhani, A.S. \& N. Lukviarman. 2009. Perbandingan Analisis Prediksi Kebangkrutan Menggunakan Model Altman Pertama, Altman Revisi dan Altman Modifikasi Dengan Ukuran dan Umur Perusahaan Sebagai Variabel Penjelas (Studi Pada Perusahaan Manufaktur yang Terdaftar di Bursa Efek Indonesia). Jurnal Siasat Bisnis. Vol. 13 No. 1.

Rochaety, Ety, dkk. 2009. Metodologi Penelitian Bisnis Dengan Aplikasi SPSS Edisi Revisi. Jakarta: Penerbit Mitra Wacana Media.

Munawir, S. 2002. Analisis Informasi Keuangan. Yogyakarta: Liberty Yogyakarta. Sembiring, S. 2006. Hukum Kepailitan dan Peraturan Perundang-undangan yang Terkait dengan Kepailitan. Bandung: Nuansa Aulia.

Simamora, B. 2005. Analisis Multivariat Pemasaran. Jakarta: PT Gramedia Pustaka Utama.

Singarimbun, M. \& S. Effendi (Eds). 1995. Metode Penelitian Survai Edisi Revisi. Jakarta: LP3ES.

Sunyoto, D. 2013. Analisis Laporan Keuangan Untuk Bisnis. Yogyakarta: Center of Academic Publishing Service (CAPS).

Surat Edaran BI No. 13/24/DPNP. "Perihal Penilaian Tingkat Kesehatan Bank Umum".

Surat Edaran BI No.12/13/Dpbs. "Tentang Pelaksanaan GCG Bagi Bank Umum".

Surat Edaran BI No.9/12/DPNP Tentang Pelaksanaan GCG Bagi Bank Umum”

Surat Edaran BI No.9/24/Dpbs/2007 Perihal Sistem Penilaian Tingkat Kesehatan Bank Umum Berdasarkan Prinsip Syariah

Undang-Undang Republik Indonesia No. 21 Tahun 2008. "Tentang Perbankan Syariah".

Undang-Undang Republik Indonesia No 37 Tahun 2004. “Tentang Kepailitan dan Penundaan Kewajiban Pembayaran Utang".

Undang-Undang Republik Indonesia No. 10 Tahun 1998. “Tentang Perubahan Atas Undang-Undang No.72 Tahun 1992 Tentang Perbankan". 
Widarjono, A. 2010. Analisis Statistika Multivariat Terapan. Yogyakarta: UPP STIM YKPN.

Yaya, R, dkk. 2013. Akuntansi Perbankan Syariah Teori dan Praktik Kontemporer, Jakarta: Salemba Empat. 